\title{
Psychosocial problems experienced by patients depending on Crohn's disease activity: an exploratory study
}

\section{BACKGROUND}

The aim of the study was to assess the effect of Crohn's disease (CD) activity and factors such as having a job, a family, or a partner on the severity of psychosocial problems experienced by them. Hypothesis: H1: CD patients who have a partner assess their psychosocial problems as less severe compared with those who do not have a partner; $\mathrm{H} 2$ : CD patients who have a job assess the severity of psychosocial problems as statistically significantly lower than those who are out of work; H3: High activity of Crohn's disease is statistically significantly associated with greater severity of psychosocial problems in CD patients.

\section{PARTICIPANTS AND PROCEDURE}

Adults with Crohn's disease, 79 women and 33 men, aged from 18 to 67 years. The activity of the disease was determined using the Crohn's Disease Activity Index (CDAI) and the severity of psychosocial problems was assessed by the Psychosocial Problems Scale.

\section{RESULTS}

Patients with high and low activity of Crohn's disease were affected by psychosocial problems in various spheres. The intensity of psychosocial problems was significantly related to the patients' labour market status and the severity of the disease symptoms.

\section{CONCLUSIONS}

A thorough understanding of the spectrum and severity of psychosocial problems faced by persons with Crohn's disease is necessary for healthcare professionals to be able to professionally address their various needs and increase their acceptance of their condition.

\section{KEY WORDS}

psychosocial problems; patient with chronic disease; Crohn's disease; quality of life; community support

ORganization - Institute of Psychology, John Paul II Catholic University of Lublin, Lublin, Poland AUthors' CONTRibutions - A: Study design - B: Data collection - C: Statistical analysis - D: Data interpretation .

E: Manuscript preparation · F: Literature search · G: Funds collection

Corresponding author - Wojciech Otrębski, Ph.D., Institute of Psychology, John Paul II Catholic University of Lublin,

Al. Racławickie 14, 20-950 Lublin, Poland, e-mail: otrebski@kul.pl

to Cite this ARTICLE - Otrębski, W., \& Krupa-Nowosad, M. (2022). Psychosocial problems experienced by patients

depending on Crohn's disease activity: an exploratory study. Health Psychology Report, 10(2), 83-92.

https://doi.org/10.5114/hpr.2021.110690

RECEIVED 05.09.2021 · REVIEWED 09.10.2021 · ACCEPTED 11.10.2021 • PUBLISHED 07.12.2021 


\section{BACKGROUND}

The functioning of patients with chronic diseases has for long been in the focus of psychological research. According to the WHO (2018), chronic diseases account for more than $70 \%$ of all causes of deaths. Moreover, the number of chronically ill persons, and the costs of their treatment, have been rising for many years now (Chodkiewicz, 2010). In order to increase the efficacy of the measures used to support these persons and their
Wojciech Otrębski,

Monika Krupa-Nowosad families, further research into their needs is necessary (Otrębski et al., 2011), especially as the objective and subjective measurements of their life quality produce different outcomes (Chodkiewicz, 2010).

Being diagnosed with a chronic disease is by all means a traumatic experience that dramatically changes the life of the patient and requires acceptance of limitations in many spheres of life (Krzysztofiak, 2011; Otrębski \& Czuba, 2014). The process of adjusting to a chronic disease is a complex one, with its course depending on a variety of factors. There is evidence that patients who struggle to adjust to their disease run a risk of developing mental, emotional and depressive disorders, and are more likely to attempt suicide (Carson et al., 2013; Engelmann et al., 2015). Many chronically ill persons and their closest ones decide to consult a psychologist or a therapist (Sykes et al., 2015).

The Hobfoll (2012) conservation of resources theory holds that human reactions, especially those triggered by stressful situations, are oriented to maintaining the existing resources and acquiring new ones. Dramatic events that abruptly change the life one has lived so far usually entail the loss of material, personal, and energy resources, etc., which are vital for chronically ill persons to cope with their disease (Block \& Otrębski, 1997; Janowski et al., 2009; Ziarko \& Sęk, 2015). The limitations imposed by it frequently deplete the resources they have accumulated and hinder the acquisition of new ones. Therefore, a better understanding of what psychological problems are specific to patients with the same condition and what resources it drains is essential to developing more effective and individualized measures for helping these patients to accept their condition and cope with it (Steuden \& Okła, 2006).

Among the various chronic diseases, Crohn's disease (CD) is particularly onerous for patients. As most of its symptoms arise from digestive system dysfunction, many CD patients have lower self-image and self-acceptance and complain about an inferior quality of life (Yanartas et al., 2016). The latter was confirmed by a recent study with CD patients with acute symptoms of the disease, who also reported that the support they were receiving was insufficient (Krupa \& Otrębski, 2020). Earlier studies, too, pointed to associations between Crohn's disease activity and the quality of life of the persons affected by it (Glise \& Wiklund, 2002; Zhou et al., 2010). An interesting analysis of the consequences of various psychosocial problems experienced by $\mathrm{CD}$ patients can be found in a study into the causes of death of $12 \mathrm{CD}$ patients conducted by the Jackson County Medical Examiner's Office in the years 2008-2010. It showed that Crohn's disease was the direct cause of death in only two of the 12 cases; in the other ten cases, psychosocial problems were involved: five persons (all of whom lived alone) died from addictions (drugs or alcohol), and the other five by suicide (Carson et al., 2013). While the sample is too small to offer firm conclusions, the findings are interesting enough to undertake in-depth research into the distinctiveness of psychosocial problems faced by CD patients.

The existing studies on patients with other chronic diseases show that their daily functioning is affected by a wide spectrum of difficulties, which are frequently specific to their disease. For instance, many patients with pulmonary arterial hypertension (PAH) feel compelled to give up employment and reduce social activity to avoid pressure from people who do not understand the character of their condition because of its relatively mild and inconspicuous symptoms. Many women with $\mathrm{PAH}$ avoid getting pregnant, which is detrimental to their relationships (PHA Europe, 2012; Tolińska, 2018). Persons with kidney inefficiency state that cognitive dysfunctions make them less productive at work and frequently result in early retirement. They also point to them as a cause of discomfort in relations with family members and friends (Rutkowski et al., 2008, as quoted in Wojczyk, 2014). As many as $66 \%$ of these patients need to rest for at least one hour before they can resume their daily duties after haemodialysis (Kraczkowska, 2010). A study investigating their quality of life has revealed an association between having a partner or a spouse and high scores for functional domains (Repka \& Wordliczek, 2013). Colostomy patients complain about their condition worsening their social, romantic and personal life. Kózka et al. (2010) found the negative effect of colostomy on the patients' intimate life to be differentiated by their sex, age, and having a life partner. It can, therefore, be concluded that having a job, a family, and a partner differentiate the functioning of patients with chronic diseases.

According to the above review, studies on persons with $\mathrm{CD}$ tend to concentrate on the consequences of the disease, such as psychological disorders or suicidal attempts. Investigations seeking to accurately map the diversity and severity of psychosocial problems faced by CD patients in relation to the severity of the symptoms are still lacking.

\section{CURRENT STUDY}

The purpose of the study was to gain an insight into psychosocial problems experienced by persons with Crohn's disease depending on the disease activity 


\section{Figure 1}

\section{Operationalisation of variables}

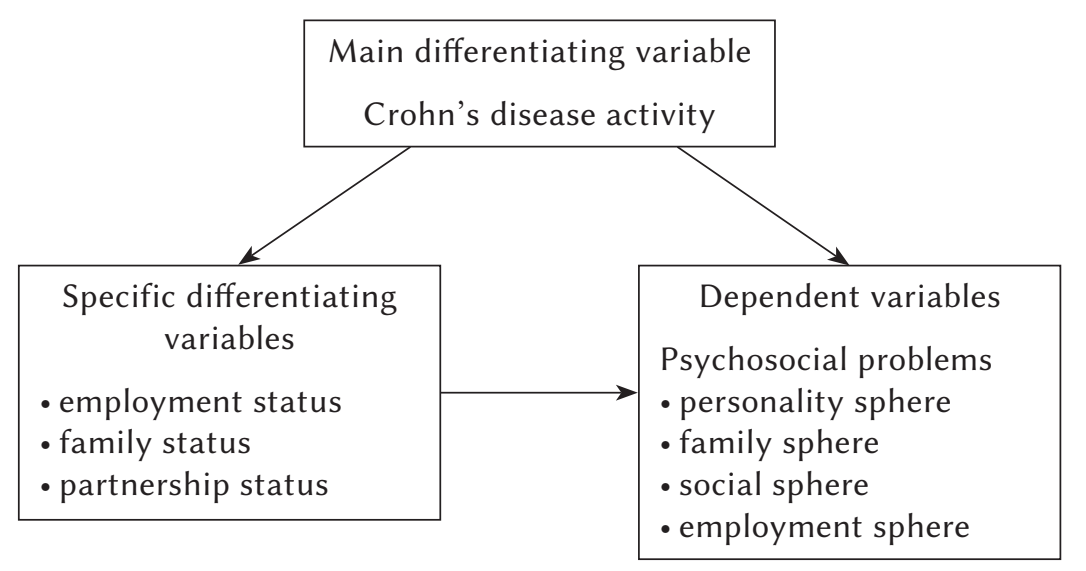

Psychosocial problems experienced by patients with Crohn's disease (low $\mathrm{CD} \downarrow$ vs. high $\mathrm{CD} \uparrow$ ) and to determine how demographic variables such as labour market status, family status, and partnership status differentiate the severity of the problems.

The study sought to answer the following specific questions:

1. How severe are psychosocial problems experienced by persons with CD $\downarrow$, and how much does their severity depend on the persons' labour market status, family status, and partnership status?

2. How severe are psychosocial problems experienced by persons with $\mathrm{CD} \uparrow$, and how much does their severity depend on the persons' labour market status, family status, and partnership status?

3. Are the differences in the severity of psychosocial problems experienced by $\mathrm{CD} \downarrow$ and $\mathrm{CD} \uparrow$ patients statistically significant and strong?

The hypotheses tested in the study were as follows:

$\mathrm{H} 1$ : CD patients who have a partner assess their psychosocial problems as less severe compared with those who do not have a partner (Repka \& Wordliczek, 2013).

$\mathrm{H} 2$ : CD patients who have a job assess the severity of psychosocial problems as statistically significantly lower than those who are out of work (Zhou et al., 2010; PHA Europe, 2012; Rutkowski et al., 2008, as quoted in Wojczyk, 2014; Tolińska, 2018).

H3: High activity of Crohn's disease is statistically significantly associated with greater severity of psychosocial problems in CD patients (Krupa \& Otrębski, 2020).

\section{PARTICIPANTS AND PROCEDURE}

\section{PARTICIPANTS}

The study was conducted with 112 patients with Crohn's disease subdivided into two groups based on the disease activity. The low disease activity group $(C D \downarrow)$ comprised 50 persons aged between 18 and 50 years $(M=29.26, S D=7.09)$ and the high disease activity group $(\mathrm{CD} \uparrow)$ consisted of 62 persons aged 18-67 years $(M=31.74, S D=10.61)$. In both groups, women, urban residents, and persons with at least secondary education predominated. The $\mathrm{CD} \downarrow$ group had statistically significantly higher percentages of persons who had jobs, did not have children, and assessed their financial situation as at least good compared with the $\mathrm{CD} \uparrow$ group (Table 1).

\section{RESEARCH TOOLS}

Two research tools were used in the study: the Crohn's Disease Activity Index (Best, 2006) and the Psychosocial Problems Scale (Witkowski et al., 2015), as well as the demographic data inventory.

The Crohn's Disease Activity Index (CDAI) is a medical calculator created by a team led by Best (1976). It is a self-completed questionnaire that allows $\mathrm{CD}$ patients to rate the severity of their disease against the following criteria: the average daily number of liquid or soft stools each day for seven days, the use of diphenoxylate or loperamide to treat diarrhoea, body temperature exceeding $37.8^{\circ} \mathrm{C}$ in the previous week, average abdominal pain rating (over seven days), general well-being each day (over seven days), the occurrence of complications (arthritis or arthralgia, iritis or uveitis, erythema nodosum, pyoderma gangrenosum or aphthous stomatitis, anal fissure, fistula or abscess, other fistula), and abdominal mass.

The total score of a patient on the CDAI is obtained by summing up the scores for particular items. Scores $\geq 150$ points indicate low disease activity (remission), whereas scores $<150$ denote reactivation of the disease (Crohn's Disease Activity Index, 2018). In this study, Cronbach's $\alpha$ obtained for the CDAI was 
Table 1

Descriptive statistics of the $C D \downarrow$ and $C D \uparrow$ groups

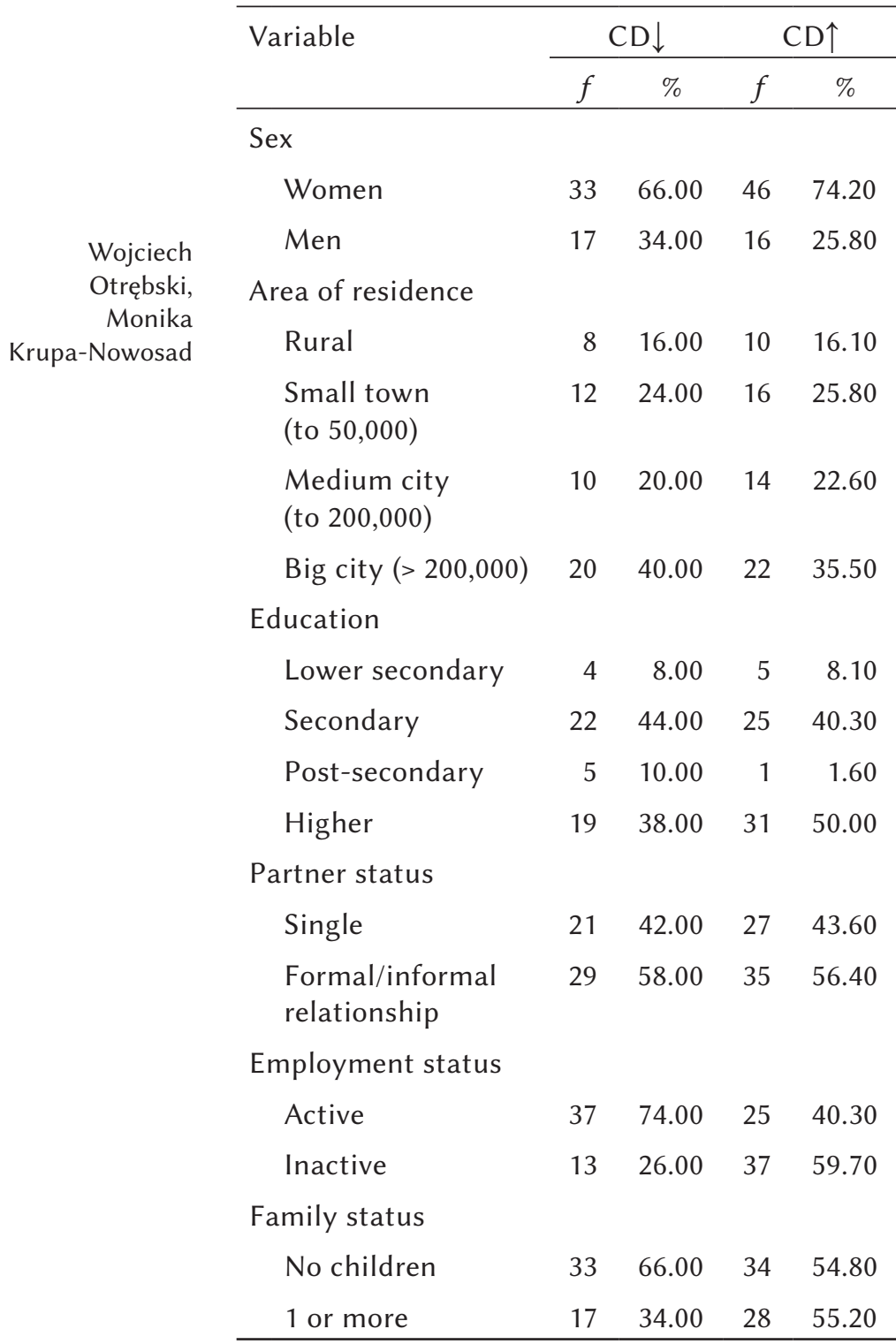

Note. $f$ - number; $\mathrm{CD} \downarrow$ - low activity of Crohn's disease;

$\mathrm{CD} \uparrow$ - high activity of Crohn's disease.

.66 , meaning that its results were suitable for scientific interpretation.

The Psychosocial Problems Scale (PCH-R; Witkowski et al., 2015) is employed to determine the severity and extent of psychosocial problems experienced by persons with chronic diseases. It consists of four spheres (personality, family, social, and employment), each containing 15 items. The total score on the PCH-R scale is computed by adding up the scores for each of the 60 items and the scores for each sphere. The higher the total score, the greater is the severity of psychosocial problems experienced by a patient and the stronger is their sense of disability. Cronbach's $\alpha$ for the total score and the scores on the spheres were .97 and $.85-.92$, respectively.

\section{PROCEDURE}

Participants were enrolled from among patients treated for Crohn's disease at specialist medical centres and the users of Crohn's disease forums. Before the study, they were briefed on its purpose and were informed they were free to withdraw from it at any time. After they expressed their consent to participate, they were sent questionnaires by surface mail. The completed questionnaires were returned in the same manner. The study was designed in compliance with the Declaration of Helsinki principles.

\section{DATA ANALYSIS}

In order to answer the research questions, statistical analysis was performed on the collected data. First, descriptive statistics (means, standard deviations) were calculated and the tests of significance of differences (the dependent sample $t$-test and the Wilcoxon Z-test) were conducted to determine the severity and extent of psychosocial problems in the $\mathrm{CD} \downarrow$ and $\mathrm{CD} \uparrow$ groups, respectively. Then, the tests of significance of differences (the independent sample $t$-test and the Mann-Whitney $U$-test) were applied again to ascertain whether employment, a family, and a partner differentiated the severity of psychosocial problems. Lastly, based on the results of the independent sample $t$-test and the Mann-Whitney $U$-test, the contents of psychosocial problems were compared between the groups. Moreover, three problems with the highest mean scores and three problems with the lowest mean scores in each sphere were analysed qualitatively to create the functioning profiles of patients with different activity of Crohn's disease.

\section{RESULTS}

\section{SEVERITY OF PSYCHOSOCIAL PROBLEMS IN THE CD $\downarrow$ GROUP}

The total score and the scores for particular spheres in the $\mathrm{CD} \downarrow$ group had normal distributions. Their mean values indicated that the severity of psychosocial problems overall and in the family and social spheres was low, whereas in the personality and employment spheres it was moderate. The intensity of psychosocial problems in the personality sphere was statistically significantly higher compared with the other spheres. Cohen's $d$ showed intermediate differences between problems in the personality sphere and in 
Table 2

Differences in the results for the spheres of psychosocial problems in the $C D \downarrow$ group

\begin{tabular}{|c|c|c|c|c|c|c|}
\hline Spheres of psychosocial functioning & M & $S D$ & $t$ & $d f$ & $p$ & $d$ \\
\hline \multirow[t]{2}{*}{1 Personality } & 38.54 & 15.59 & 7.43 & 49 & .001 & .60 \\
\hline & 28.58 & 17.49 & & & & \\
\hline \multirow[t]{2}{*}{2 Personality } & 38.54 & 15.59 & 7.97 & 49 & .001 & .89 \\
\hline & 28.78 & 17.00 & & & & \\
\hline \multirow[t]{2}{*}{3 Personality } & 38.54 & 15.59 & 5.56 & 49 & .001 & .44 \\
\hline & 30.78 & 19.16 & & & & \\
\hline \multirow[b]{2}{*}{ Social functioning } & 28.58 & 17.49 & -0.13 & 49 & .900 & - \\
\hline & 28.78 & 17.00 & & & & \\
\hline \multirow[b]{2}{*}{ Employment } & 28.58 & 17.49 & -1.77 & 49 & .080 & - \\
\hline & 30.78 & 19.16 & & & & \\
\hline \multirow[t]{2}{*}{6 Social functioning } & 28.78 & 17.00 & -1.65 & 49 & .110 & - \\
\hline & 30.78 & 19.16 & & & & \\
\hline
\end{tabular}

Note. $t$ - dependent samples test statistic; $d f$ - number of degrees of freedom; $d$-Cohen's d; CD $\downarrow$ - low activity of Crohn's disease.

the family and employment spheres, and a large difference between problems in the personality sphere and the social sphere (Table 2). Therefore, while persons with CD $\downarrow$ may function relatively well in the social functioning, family, and employment spheres, they still have emotional problems and struggle with accepting their disease and its limitations.

\section{DEMOGRAPHIC VARIABLES AS FACTORS \\ DIFFERENTIATING THE SEVERITY OF PSYCHOSOCIAL PROBLEMS IN THE CD $\downarrow$ GROUP}

The analysis of the mean values of psychosocial problems with respect to the selected demographic variables did not find them to significantly differentiate the total score or the scores for particular spheres in the $\mathrm{CD} \downarrow$ group (Table 3).

\section{SEVERITY OF PSYCHOSOCIAL PROBLEMS IN THE CD $\uparrow$ GROUP}

The $\mathrm{CD} \uparrow$ group was analysed using the same approach. In this group, only the scores for the social sphere had a normal distribution; the distributions of the total score and scores for the other spheres were left-skewed, meaning that more participants had higher-than-average scores on these spheres because they perceived them as more severe. The mean total score and mean scores for three of the spheres (personal, family, and social functioning) were average; the mean score for the fourth sphere (employment) was high. This means that the participants in the $\mathrm{CD} \uparrow$ group considered Crohn's disease and its symptoms onerous and had a nagging sense of disability in different spheres of life because of the symptoms' intensity. The results of the tests of significance of differences indicated that psychosocial problems experienced in the personality and employment spheres were significantly more severe than in the family and social spheres, with the effect sizes indicating that the differences were intermediate apart from one pair for which they were large. Therefore, the $\mathrm{CD} \uparrow$ patients were pessimistic about the sense of struggling and emotionally upset, and viewed the workplace as a stressful environment where they did not feel very comfortable, accepted, and safe (Table 4).

\section{THE DIFFERENTIATING EFFECT}

\section{OF THE SELECTED DEMOGRAPHIC VARIABLES ON THE SEVERITY OF PSYCHOSOCIAL PROBLEMS IN THE CD $\uparrow$ GROUP}

In the $\mathrm{CD} \uparrow$ group, the employment status proved to be the only demographic variable that significantly differentiated the intensity of psychosocial problems (overall, and in the family, social, and employment spheres) (Table 5).

The results in Table 5 show that psychosocial problems are perceived as more severe by $\mathrm{CD} \uparrow$ patients who do not work compared with those who have a job. The effect sizes indicate that the differences are large. It seems, therefore, that having a job

\section{Psychosocial problems experienced by patients with Crohn's disease}


Table 3

The differentiating effect of selected demographic variables on the severity of psychosocial problems in the $C D \downarrow$ group

Wojciech

Otrębski,

Monika Krupa-Nowosad

\begin{tabular}{|c|c|c|c|c|c|c|}
\hline $\begin{array}{l}\text { Demographic } \\
\text { variable }\end{array}$ & $\begin{array}{c}\text { Spheres of psychosocial } \\
\text { functioning }\end{array}$ & Mean rank & Mean rank & $U$ & $p$ & $r$ \\
\hline \multirow{6}{*}{$\begin{array}{l}\text { Labour market } \\
\text { status }\end{array}$} & & Active & Inactive & & & \\
\hline & Total score & 22.06 & 24.00 & 155.0 & .690 & - \\
\hline & Personality & 26.46 & 22.77 & 205.0 & .430 & - \\
\hline & Family & 25.04 & 26.81 & 223.5 & .710 & - \\
\hline & Social & 25.78 & 24.69 & 230.0 & .820 & - \\
\hline & Employment & 25.39 & 25.81 & 236.5 & .930 & - \\
\hline \multirow[t]{6}{*}{ Family status } & & 1 or more & No children & & & \\
\hline & Total score & 19.03 & 24.48 & 168.5 & .180 & - \\
\hline & Personality & 24.59 & 25.97 & 265.0 & .750 & - \\
\hline & Family & 24.65 & 25.94 & 266.0 & .770 & - \\
\hline & Social & 23.68 & 26.44 & 249.5 & .530 & - \\
\hline & Employment & 20.88 & 27.88 & 202.0 & .110 & - \\
\hline \multirow[t]{6}{*}{ Partner status } & & $\begin{array}{l}\text { Formal/informal } \\
\text { relationship }\end{array}$ & Single & & & \\
\hline & Total score & 20.72 & 25.32 & 181.5 & .250 & - \\
\hline & Personality & 24.97 & 26.24 & 289.0 & .760 & - \\
\hline & Family & 23.10 & 28.81 & 235.0 & .170 & - \\
\hline & Social & 24.97 & 26.24 & 289.0 & .760 & - \\
\hline & Employment & 23.66 & 28.05 & 251.0 & .290 & - \\
\hline
\end{tabular}

Note. $U$ - Mann-Whitney; $r$ - effect size; CD $\downarrow$ - low activity of Crohn's disease.

\section{Table 4}

Differences in the results for the spheres of psychosocial problems in the CD $\uparrow$ group

\begin{tabular}{|c|c|c|c|c|c|}
\hline Spheres of psychosocial functioning & M & $S D$ & $Z$ & $p$ & $r$ \\
\hline 1 Personality & 47.77 & 13.31 & -3.15 & .002 & .31 \\
\hline Family & 42.19 & 18.67 & & & \\
\hline 2 Personality & 47.77 & 13.31 & -4.44 & .001 & .44 \\
\hline Social & 41.05 & 15.28 & & & \\
\hline 3 Personality & 47.77 & 13.31 & -1.41 & .160 & - \\
\hline Employment & 45.23 & 17.92 & & & \\
\hline 4 Family & 42.19 & 18.67 & -1.08 & .280 & - \\
\hline Social & 41.05 & 15.28 & & & \\
\hline 5 Family & 42.19 & 18.67 & -2.55 & .010 & .25 \\
\hline Employment & 45.23 & 17.92 & & & \\
\hline 6 Social & 41.05 & 15.28 & -3.03 & .002 & .30 \\
\hline Employment & 45.23 & 17.92 & & & \\
\hline
\end{tabular}


Table 5

The differentiating effect of selected demographic variables on the severity of psychosocial problems the CD $\uparrow$ group

\begin{tabular}{|c|c|c|c|c|c|c|}
\hline $\begin{array}{l}\text { Demographic } \\
\text { variable }\end{array}$ & $\begin{array}{c}\text { Spheres of psychosocial } \\
\text { functioning }\end{array}$ & Mean rank & Mean rank & $U$ & $p$ & $r$ \\
\hline \multirow{6}{*}{$\begin{array}{l}\text { Labour market } \\
\text { status }\end{array}$} & & Active & Inactive & & & \\
\hline & Total score & 22.07 & 31.23 & 232.5 & .030 & .73 \\
\hline & Personality & 28.64 & 33.43 & 391.0 & .300 & - \\
\hline & Family & 24.72 & 36.08 & 293.0 & .010 & .70 \\
\hline & Social & 25.84 & 35.32 & 321.0 & .040 & .68 \\
\hline & Employment & 24.98 & 35.91 & 299.5 & .020 & .69 \\
\hline \multirow[t]{6}{*}{ Family status } & & 1 or more & No children & & & \\
\hline & Total score & 26.92 & 27.97 & 346.0 & .810 & - \\
\hline & Personality & 29.95 & 32.78 & 432.5 & .540 & - \\
\hline & Family & 27.43 & 34.85 & 362.0 & .110 & - \\
\hline & Social & 27.80 & 34.54 & 372.5 & .140 & - \\
\hline & Employment & 28.89 & 33.65 & 403.0 & .300 & - \\
\hline \multirow[t]{6}{*}{ Partner status } & & $\begin{array}{l}\text { Formal/informal } \\
\text { relationship }\end{array}$ & Single & & & \\
\hline & Total score & 27.19 & 27.91 & 347.0 & .870 & - \\
\hline & Personality & 32.24 & 30.54 & 446.5 & .710 & - \\
\hline & Family & 29.09 & 34.63 & 388.0 & .230 & - \\
\hline & Social & 29.26 & 34.41 & 394.0 & .270 & - \\
\hline & Employment & 30.31 & 33.04 & 431.0 & .560 & - \\
\hline
\end{tabular}

Note. $U$ - Mann-Whitney; $r$ - effect size; $\mathrm{CD} \uparrow$ - high activity of Crohn's disease.

has a significant bearing on how these patients rate their functioning in the family, social, and employment spheres. It is also notable that $\mathrm{CD} \uparrow$ patients have similar problems, believing in the sense of struggling and accepting their disease and functional limitations regardless of whether they are employed or not; the observation implies that both these subgroups may need psychological support or therapy.

\section{ACTIVITY LEVEL OF CROHN'S DISEASE} AS A FACTOR DIFFERENTIATING THE INTENSITY OF PSYCHOSOCIAL PROBLEMS IN CD $\downarrow$ AND CD $\uparrow$ GROUPS

The analysis of between-group differences provided convincing evidence that the intensity and onerousness of psychosocial problems in the $\mathrm{CD} \uparrow$ group were twice as high as in the CD $\downarrow$ group, with the effect sizes of the differences being small or intermediate (Table 6).

\section{PSYCHOSOCIAL FUNCTIONING PROFILES OF PERSONS WITH CD $\downarrow$ AND CD $\uparrow$}

Lastly, the content of questionnaire items with the highest and lowest mean scores in each sphere was examined to learn more about the character of psychosocial problems experienced by the study participants. The analysis revealed that both groups experienced the same difficulties, although with different intensity.

All participants felt a strong desire to be ablebodied and healthy and were anxious that the symptoms might progress, rendering them unable to work. They easily made new acquaintances and did not mind questions about their disease or being offered assistance. At the same time, they disliked being pitied, felt a need to return favours given to them, and had a strong awareness of the need to help others. They believed that they could have a happy marriage and did not think that their disease might complicate their romantic life.
Psychosocial problems experienced by patients with Crohn's disease 
Table 6

Differences between the results obtained for $C D \downarrow$ and $C D \uparrow$ groups

\begin{tabular}{lcccccccc}
\hline & \multicolumn{2}{c}{$\mathrm{CD} \downarrow$} & \multicolumn{2}{c}{$\mathrm{CD} \uparrow$} & \multicolumn{3}{c}{ Significance test } & \multirow{2}{*}{$d$} \\
\cline { 2 - 7 } & $M$ & $S D$ & $M$ & $S D$ & $t$ & $d f$ & $p$ \\
\hline Total results & 130.89 & 66.92 & 173.89 & 64.19 & -3.24 & 96 & .002 & .66 \\
Personal sphere & 39.60 & 15.22 & 46.89 & 14.39 & -2.55 & 106 & .010 & .49 \\
Family sphere & 29.60 & 17.52 & 41.27 & 19.41 & -3.21 & 104 & .002 & .63 \\
Social sphere & 29.70 & 17.14 & 40.53 & 16.21 & -3.30 & 102 & .001 & .65 \\
Employment sphere & 31.41 & 19.47 & 45.42 & 18.08 & -3.82 & 105 & .001 & .75 \\
\hline
\end{tabular}

Note. $t$ - independent samples test statistics; $d f$ - the number of degrees of freedom; $d$-Cohen's d; CD $\downarrow-$ low activity of Crohn's disease; $C D \uparrow$ - high activity of Crohn's disease.

Participants in the $\mathrm{CD} \downarrow$ group wished to stay in employment despite their functional limitations. They wanted to demonstrate their professionalism and proactively pursued job opportunities, believing in their abilities. Their disease did not affect their employability and was not a hindrance in getting a job matching their education and skills, but assistance offered by co-workers made them feel uncomfortable. They deemed their social life interesting and knew how to take care of themselves. Household chores were not a problem for them, but they realised that they had poor chances of participating in sports.

The $\mathrm{CD} \uparrow$ group participants hoped that a therapy would be developed that would bring them back to health. They did not think their families did not trust their common sense and tried to control them, and were upset by other people not treating them as "normal" persons. They felt uncomfortable at the thought that some jobs were beyond their physical capacity and worried whether they would be able to work in the future. At the same, however, they were confident in their employability and made efforts to have a job. They did not think that people with chronic diseases are disliked by co-workers.

\section{DISCUSSION}

In the study, psychosocial problems experienced by patients with high and low activity of Crohn's disease (CD $\downarrow$ vs. $C D \uparrow)$ were analysed quantitatively and qualitatively to determine their severity and content. The outcomes of the analyses were compared between the two groups of patients. The hypotheses tested in the study were that a partner status, a job, or milder symptoms of Crohn's disease were associated with less severe psychosocial problems, whereas being single, joblessness, and acute symptoms aggravated them.
The first of the hypotheses was not confirmed. Having a spouse or a partner did not differentiate the intensity of psychosocial problems among the studied CD patients. Therefore, being in a relationship did not help them to avoid daily functioning difficulties, in contrast with what is reported for patients with other chronic diseases (Kózka et al., 2010; Repka \& Wordliczek, 2013).

The second hypothesis was only partially confirmed. Only the $\mathrm{CD} \uparrow$ group participants who had jobs reported lower intensity of psychosocial problems. While the result is inconclusive, it shows that employment significantly influences patients' assessments of their functioning in the family, social spheres and in the work place. It is consistent with the conservation of resources theory that the depletion of one resource initiates the loss of other resources (Hobfoll, 2012). The similar intensity of psychosocial problems (with believing in the sense of struggling and accepting the disease and functional limitations) between participants who were employed and those who did not have a job suggests that $\mathrm{CD} \uparrow$ patients may need psychological support or therapy regardless of their labour market status.

The third hypothesis was fully supported by the study results. An association was found between the activity of Crohn's disease and the patients' assessments of the severity of psychosocial problems. The acuteness of symptoms in the $\mathrm{CD} \uparrow$ group participants made them painfully aware of their disability in different spheres of daily functioning, eroded their belief in the sense of struggling, and upset them emotionally. The work environment was especially stressful for them because they did not feel quite comfortable, accepted, and safe in it. This aspect certainly deserves more attention in working with patients with acute $\mathrm{CD}$ symptoms.

The analysis of individual psychosocial problems indicated by the participants as the most severe showed that their content was similar in many ways 
between the study groups. This seems to suggest that some problems are common to CD patients regardless of the intensity of the symptoms.

\section{LIMITATIONS}

The study has two main limitations that may have influenced its findings. One of them is related to the large difference in Crohn's disease activity between the study groups. The other limitation follows from the lack of indicators enabling objective measurements of the inflammatory activity of the disease. It seems that in the future research it could be circumvented through cooperation with clinics specialising in the treatment of Crohn's disease, which have clinical expertise necessary to evaluate the intensity of Crohn's disease symptoms.

Future research projects on patients with Crohn's disease should also consider the role of concomitant conditions, including depression, anxiety, and other mental health disorders. The role of therapeutic interventions in mitigating the intensity of particular problems affecting the psychosocial functioning of the patients should also be assessed.

It also seems important to explore factors helping patients with Crohn's disease to accept their condition because such investigations could improve our understanding of the difficulties they face in the personality sphere.

\section{PRACTICAL APPLICATIONS}

This study is intended for those who live with people with Crohn's disease and the specialists supporting them. Its results highlight psychosocial problems specific to $\mathrm{CD}$ patients with different severity of symptoms and indicate areas in which they need special attention and support. They also offer two important suggestions. Firstly, it is necessary to establish a professional and formalised system of psychological support for patients at different stages of the disease. Secondly, the system should be effective in identifying patients who need psychological support to deal with the impacts of their disease and accept limitations in various aspects of life.

The practical conclusions that can be drawn from the study are as follows:

1. People living with Crohn's disease need psychological support regardless of the intensity of the disease because they perceive themselves as disabled and struggle to accept their condition.

2. People with more severe $\mathrm{CD}$ symptoms have a special need for vocational guidance and employability assessment services helping them identify jobs matching their limitations and physical capabilities.
3. Professional support programmes for CD patients should take advantage of their personal resources such as the ability to develop good relationships with other people, helpfulness, and a wish to talk about their disease.

\section{References}

Block, B., \& Otrębski, W. (Eds.) (1997). Człowiek nieuleczalnie chory [An incurably ill man]. WNS KUL.

Best, W. R. (2006). Predicting the Crohn's disease activity index from the Harvey-Bradshaw Index. Inflammatory Bowel Diseases, 12, 304-310. https:// doi.org/10.1097/01.MIB.0000215091.77492.2a

Best, W. R., Becktel, J. M., Singleton, J. W., \& Kern, F. Jr. (1976). Development of a Crohn's disease activity index. National Cooperative Crohn's Disease Study. Gastroenterology, 70, 439-444.

Carson, H. J., Dudley, M., Knight, L. D., \& Lingamfelter, D. (2013). Psychosocial complications of Crohn's disease and cause of death. Journal of Forensic Sciences, 59, 568-570. https://doi.org/ 10.1111/1556-4029.12314

Chodkiewicz, J. (2010). Psychologia zdrowia. Wybrane zagadnienia [Health psychology. Selected Issues]. Wydawnictwo Wyższej Szkoły HumanistycznoEkonomicznej w Łodzi.

Crohn's Disease Activity Index (2018). Crohn's Disease Activity Index (CDAI). Retrieved from https:// www.merckmanuals.com/medical-calculators/ CDAI.htm [accessed November 10, 2018]

Engelmann, G., Erhard, D., \& Petersen, M. (2015). Health-related quality of life in adolescents with inflammatory bowel disease depends on disease activity and psychiatric comorbidity. Child Psychiatry \& Human Development, 46, 300-307. https:// doi.org/10.1007/s10578-014-0471-5

Glise, H., \& Wiklund, I. (2002). Health-related quality of life and gastrointestinal disease. Journal of Gastroenterology and Hepatology, 17, 72-84. https:// doi.org/10.1046/j.1440-1746.17.s1.6.x

Hobfoll, S. E. (2012). Teoria zachowania zasobów i jej implikacje dla problematyki stresu, zdrowia i odporności [The theory of resource conservation and its implications for stress, health and resilience]. In E. Bielawska-Batorowicz \& B. Dudek (Eds.), Teoria zachowania zasobów Stevana E. Hobfolla. Polskie doświadczenia [Stevan E. Hobfoll's theory of conservation of resources. Polish experiences] (pp. 17-42). Wydawnictwo Uniwersytetu Łódzkiego.

Janowski, K., Steuden, S., Kuryłowicz, J., \& Nieśpiałowska-Steuden, M. (2009). The Disease-Related Appraisals Scale: a tool to measure subjective perception of the disease situation. In K. Janowski \& S. Steuden (Eds.), Biopsychosocial aspects of health and disease (Vol. 1, pp. 108-125). CPPP Scientific Press.
Psychosocial problems experienced by patients with Crohn's disease 
Kózka, M., Bazaliński, D., Jakubowski, K., \& Pudło, M. (2010). Determinanty funkcjonowania psychospołecznego osób z przetoką jelitową [Determinants of psychosocial functioning in people with intestinal fistula]. Pielegniarstwo Chirurgiczne i Angiologiczne, 4, 123-129.

Kraczowska, H. (2010). Problemy emocjonalne pacjentów hemodializowanych otrzewnowo [Emotional problems of peritoneal hemodialysis patients]. Forum Nefrologiczne, 3, 212-216.

Wojciech

Otrębski,

Monika

Krupa-Nowosad

Krupa, M., \& Otrębski, W. (2020). Uwarunkowania jakości życia pacjentów z chorobą Leśniowskiego-Crohna - rola wsparcia społecznego [Determinants of the quality of life of patients with Crohn's disease - the role of social suport]. In E. Zasępa (Ed.), Jakość życia człowieka w zdrowiu $i$ chorobie [The quality of human life in health and disease] (pp. 222-260). Difin.

Krzysztofiak, D. (2011). Długotrwała lub ciężka choroba. Rzecz o wspieraniu człowieka w sytuacji niemocy [Long-term or severe disease. It's about supporting a person in a situation of helplessness]. In E. Włodarczyk \& I. Cytlak (Eds.), Człowiek wobec krytycznych sytuacji życiowych. Z teorii i praktyki pracy socjalnej [Man in the face of critical life situations. From the theory and practice of social work] (pp. 93-107). Wydawnictwo Naukowe UAM.

Otrębski, W., \& Czuba, B. (2014). Coping with stress amongst families with children suffering from chronic psychosomatic diseases - recommendations for psychoprophylactic action. In T. M. Ostrowski \& I. Sikorska (Eds.), Health and resilence (pp. 157-168). Wydawnictwo Uniwersytetu Jagiellońskiego.

Otrębski, W., Mariańczyk, K., Konefał, K., \& Kulik, M. (2011). Wspieranie rodziny z niepełnosprawnym dzieckiem wyzwaniem dla pracy socjalnej. Badania rodzin $z$ niepełnosprawnymi dziećmi w województwie lubelskim [Supporting a family with a disabled child as a challenge for social work. Research on families with disabled children in the Lubelskie Voivodeship]. Europerspektywa.

Pulmonary Hypertension Association (PHA) Europe (2012). The impact of pulmonary arterial hypertension (PAH) on lives of patients and carers: Results from an international survey. Retrieved from www.phaeurope.org/wp-content/uploads/PAH_ Survey_FINAL.pdf

Repka, I., \& Wordliczek, J. (2013). Wpływ czynników demograficzno-społecznych na natężenie bólu, jakość życia oraz jej poszczególne składowe wśród chorych z bólem przewlekłym [The influence of demographic and social factors on pain intensity, quality of life and its individual components in patients with chronic pain]. Problemy Pielegniarstwa, 21, 348-359.

Steuden, S., \& Okła, W. (2006). Czynniki sprzyjające podnoszeniu jakości życia w sytuacji choroby [Fac- tors contributing to improving the quality of life in the event of an illness]. In S. Steuden \& W. Okła (Eds.), Jakość życia w chorobie [Quality of life in illness] (pp. 195-208). Wydawnictwo KUL.

Sykes, D., Fletcher, P., \& Schneider, M. (2015). Balancing my disease: Women's perspectives of living with inflammatory bowel disease. Journal of Clinical Nursing, 24, 2133-2142. https://doi.org/10.1111/ jocn. 12785

Tolińska, K. (2018). Psychospołeczne i emocjonalne funkcjonowanie pacjentów z tętniczym nadciśnieniem płucnym [Psychosocial and emotional functioning of patients with pulmonary arterial hypertension]. Sztuka Leczenia, 1, 51-63.

WHO (2018). Noncommunicable diseases. Retrieved from https://www.who.int/news-room/fact-sheets/ detail/noncommunicable-diseases

Witkowski, T., Otrębski, W., Wiącek, G., Czusz, A., \& Mariańczyk K. (2015). Narzędzia pomiaru w psychologii rehabilitacji. Część I [Measurement tools in rehabilitation psychology. Part I.]. Pracownia Testów Psychologicznych i Pedagogicznych.

Wojczyk, A. (2014). Problemy codziennego życia hemodializowanych pacjentów [Problems of everyday life in hemodialysis patients]. Pielęgniarstwo i Zdrowie Publiczne, 4, 143-148.

Yanartas, O., Kani, H. T., Bicakci, E., Kilic, I., Banzgragch, M., Acikel, C., Atug, O., Kuscu, K., Imeryuz, N., \& Akin, H. (2016). The effects of psychiatric treatment on depression, anxiety, quality of life, and sexual dysfunction in patients with inflammatory bowel disease. Neuropsychiatric Disease and Treatment, 12, 673-683. https://doi.org/10.2147/ NDT.S106039

Zhou, Y., Ren, W., Irvine, E. J., \& Yang, D. (2010). Assessing health-related quality of life in patients with inflammatory bowel disease in Zhejiang, China. Journal of Clinical Nursing, 19, 79-88. https:// doi.org/10.1111/j.1365-2702.2009.03020.x

Ziarko, M., \& Sęk, H. (2015). Znaczenie zasobów osobistych w zmaganiu się z przewlekłą chorobą i jej konsekwencjami - implikacje dla pomocy psychologicznej [The importance of personal resources in coping with chronic illness and its consequences - implications for psychological help]. Przegląd Psychologiczny, 58, 277-290. 